\title{
Evaluation of Biological Control Traits in Some Isolates of Fluorescent Pseudomonads and flavobacterium
}

\author{
Ali-Ashraf Soltani (Corresponding author) \\ Department of soil science, college of agriculture, University of Tehran, Karaj, Iran \\ Tel: 98-911-382-3313_E-mail: ali_soltani_t@yahoo.com \\ Kazem Khavazi \\ Soil and Water Research Institute, Karaj, Tehran, Iran \\ E-mail: kkhavazi@yahoo.com \\ Hadi Asadi-Rahmani \\ Soil and Water Research Institute, Karaj, Tehran, Iran \\ E-mail: Asadi_1999@yahoo.com \\ Hossein-Ali Alikhani \\ Department of soil science, college of agriculture, University of Tehran, Karaj, Iran \\ E-mail: Halikhani@ut.ac.it \\ Mahtab Omidvari \\ Department of plant pathology, college of agriculture, University of Tehran, Karaj, Iran \\ E-mail: vania_vandad@yahoo.com \\ Payman Abaszadeh Dahaji \\ Department of soil science, college of agriculture, University of Tehran, Karaj, Iran \\ E-mail: dahaji@ut.ac.ir
}

Received: December 29, 2010

Accepted: January 21, $2011 \quad$ Online Published: XX

doi:10.5539/jas.v4n1p164

URL: http://dx.doi.org/10.5539/jas.v4n1p164

\begin{abstract}
Plant growth promoting rhizobacteria (PGPR) consisting a wide range of beneficial soil bacteria inhabiting rhizosphere of plant. Fluorescent pseudomondas are the most important plant growth promoting rhizosphere bacteria in different crop plants. In this research, twenty-five isolates of fluorescent pseudomonads isolated from forty soil samples of wheat rhizosphere and forty four isolates of Flavobacterium selected from the bacterial strains collection were employed. The ability of these isolates for production of chitinase, Salicylic acid, siderophore and hydrogen cyanide and antifungal activity against Rhizoctonia solani were determined. Results revealed that all the fluorescent pseudomonads isolates were able to produce siderophore on Chrome Azurol S (CAS) agar plates and siderophore is an important secondary metabolite in plant growth promotion and antifungal activity. In CAS agar method, the range of siderophore production was 0.34-1.21 halo diameter per colony diameter. None of these isolates were capable for chitinase production. Salicylic acid (SA) production by the isolates ranging from 0-10.91 g. ml ${ }^{-1}$ (average $2.48 \mathrm{~g} \cdot \mathrm{ml}^{-1}$ ). Bacterial ability for production of hydrogen cyanide had a great variation and based on this ability they were qualitatively classified in to high, relatively high, moderate and no production. Productions of studied metabolites were not detected in Flavobacterium isolates. Three isolates (PA24, PA1 and PA18) of fluorescent pseudomonads showed in vitro antifungal activity against Rhizoctonia solani. In contrast none of Flavobacterium isolates showed growth inhibition against the tested fungus. Results of this study showed that fluorescent pseudomonads which are native to soils of Iran had the
\end{abstract}


potential to be used for promotion of plant growth and suppression of soil-borne plant pathogens. In contrast, Flavobacterium seem to be an inefficient rhizobacterium against plant pathogens because of incapability to production of some important secondary metabolites in plant growth promotion and antifungal activity. There is a need to study their effects on different agricultural crops.

Keywords: Chitinase, Flavobacterium, Fluorescent pseudomonads, Hydrogen cyanide, Rhizoctonia solani, Salicylic acid and siderophore

\section{Introduction}

The bacteria that exert some beneficial effects on plant growth are two general types, those that form a symbiotic relationship with the plant and those that are free-living in the soil. Beneficial free-living soil bacteria are usually referred to as plant growth-promoting rhizobacteria or PGPR (Kloepper et al., 1989). These bacteria can stimulate plant growth either directly or indirectly (Glick, 1995). PGPRs increase plant growth indirectly either by the suppression of well-known diseases caused by major pathogens or by reducing the deleterious effects of miner pathogens (Whipps, 2001; Someya, 2008). Antibiotic synthesis (Kaaijmakers and Weller, 2001), siderophore production (Alexander and Zuberer, 1991), extra cellular enzymes such as, chitinase, $\beta-1,3$ glucanase production (Nagarajkumar et al., 2004) and Competition for nutrients and space in rhizosphere are some indirect mechanisms used by bacteria (Schippers et al., 1990). The direct stimulation of plant development by PGPRs includes either providing the plant with a compound such as, Phytohormones (Glick, 1995), ACC-deaminase enzyme (Glick et al., 1994), that is synthesized by the bacteria or simplifying the uptake of certain nutrients such as phosphorus from the soil (Raju and Reddy, 1999). PGPRs include a number of different soil bacteria such as, Pseudomonas, Azospirillum, Burkholderia, Enterobacter, Azotobacter, Serratia, Alcaligenes, Arthrobacter, Acinetobacter, Flavobacterium and Bacillus species (Glick, 1995; Rodriguez and Fraga, 1999; Sturz and Nowak, 2000; Bloemberg and Lugtenberg, 2001). Bacteria in the genera of fluorescent pseudomonds have captured special attention over the last ten years for their beneficial and deleterious effects on plant development. Mechanisms of biological control of plant pathogens by fluorescent pseudomonads generally involve production of bacterial metabolites such as siderophores, hydrogen cyanide, extra cellular lytic enzymes and induced systemic resistance (O,Sullivan and O,Gara, 1992). Furthermore, Flavobacterium is an efficient rhizosphere genus in promotion of plant growth (Asghar et al., 2004). Nevertheless, to our knowledge, no report has been published on biological control ability of this genus. This study was carried out to evaluate the potential for production of chitinase, salicylic acid, hydrogen cynanide and siderophore by isolates of fluorescent pseudomonds and Flavobacterium. Also antifungal activity of these isolates was investigated against Rhizoctonia solani as a major soil-borne pathogen.

\section{Material and Methods}

\subsection{Bacteria Isolates}

Fluorescent Pseudomonds were isolated from the forty soil samples of wheat rhizosphere collected from different location of Iran with King's medium B (king et al.,1954) as described by vidhyasekaran et al.(1997). The isolates were identified as species of fluorescent pseudomonads according to Bergey,s Manual of Systematic Bacteriology (Krieg and Holt, 1984). Forty for isolates of Flavobacterium were selected from biological research section bacterial collection of soil and water research institute, Tehran, Iran.

\subsection{Production of siderophore}

Siderophore production by strains was detected as described by Alexander and Zuberer (1991). CAS agar was prepared from four solutions which were sterilized separately before mixing. The Fe-CAS indicator solution (solution 1) was prepared by mixing $10 \mathrm{ml}$ of $1 \mathrm{mM} \mathrm{FeCl}_{3} \cdot 6 \mathrm{H}_{2} \mathrm{O}$ [in $10 \mathrm{mM} \mathrm{HCl}$ ] with $50 \mathrm{ml}$ of an aqueous solution of CAS (1.21 mg.ml $\left.{ }^{-1}\right)$. The resulting dark purple mixture was added slowly, with constant stirring, to $40 \mathrm{ml}$ of an aqueous solution of HDTMA $\left(1.82 \mathrm{mg} \cdot \mathrm{ml}^{-1}\right)$. This yielded a dark blue solution which was autoclaved, then cooled to $50^{\circ} \mathrm{C}$.

The buffer solution (solution 2) was prepared by dissolving $30.24 \mathrm{~g}$ of PIPES in $750 \mathrm{ml}$ of a salt solution containing $0.3 \mathrm{~g} \mathrm{KH}_{2} \mathrm{PO}_{4}, 0.5 \mathrm{~g} \mathrm{NaCl}$ and $1.0 \mathrm{~g} \mathrm{NH}_{4} \mathrm{Cl}$. The $\mathrm{pH}$ was adjusted to 6.8 with $50 \% \mathrm{KOH}$ and water was added to bring the volume to $800 \mathrm{ml}$. The solution was autoclaved after adding $15 \mathrm{~g}$ of agar, and then cooled to $50^{\circ} \mathrm{C}$. Solution 3 contained the following (in $70 \mathrm{ml}$ water): $2 \mathrm{~g}$ glucose, $2 \mathrm{~g}$ mannitol, $493 \mathrm{mg} \mathrm{MgSO} \mathrm{Mg}_{4} .7 \mathrm{H}_{2} \mathrm{O}, 11$ $\mathrm{mg} \mathrm{CaCl}, 1.17 \mathrm{mg} \mathrm{MnSO}_{4} \cdot \mathrm{H}_{2} \mathrm{O}, 1.4 \mathrm{mg} \mathrm{H}_{3} \mathrm{BO}_{3}, 0.04 \mathrm{mg} \mathrm{CuSO}{ }_{4} .5 \mathrm{H}_{2} \mathrm{O}, 1.2 \mathrm{mg} \mathrm{ZnSO} 4.7 \mathrm{H}_{2} \mathrm{O}$ and $1.0 \mathrm{mg}$ $\mathrm{Na}_{2} \mathrm{MoO}_{4} \cdot 2 \mathrm{H}_{2} \mathrm{O}$. Solution 3 was autoclaved, cooled to $50^{\circ} \mathrm{C}$. Then added to the buffer solution along with $30 \mathrm{ml}$

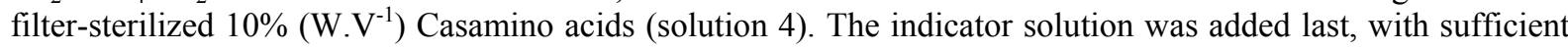
stirring to mix the ingredients without forming bubbles. Media was poured into sterilized plates after solidification of media a loop full of each strain which was cultured in rich medium (TSB) was placed on the plates (three per plate), and the plates were incubated at $27^{\circ} \mathrm{C}$ for three days. Change in the dye color from blue 
to orange indicated production of siderophore. The ratio of halo diameter per colony diameter was daily evaluated.

\subsection{Production of Hydrogen Cyanide}

Hydrogen cyanide $(\mathrm{HCN})$ production from glycine was tested by growing the bacteria in $10 \%$ tryptic soy agar (TSA) supplemented with glycine $\left(4.4\right.$ g. $\left.\mathrm{L}^{-1}\right)$ and cyanogenesis was revealed using picric acid and $\mathrm{Na}_{2} \mathrm{CO}_{3}(0.5$ and $2 \%$, respectively) impregnated filter paper fixed to the underside of the Petri dish lids. Results were read after 5 days of culture at $28^{\circ} \mathrm{C}$. A change in filter paper color from yellow to orange-brown indicated cyanide production (yellow (1): no cyanide production, orange (2): moderate cyanide production, light brown (3): relatively high cyanide production and brown (4): high cyanide production), (Donate-Correa et al., 2004).

\subsection{Production of Chitinase}

A $20 \mathrm{~g}$ sample of crab-shell chitin was dissolved in cold concentrated $\mathrm{HCl}(350 \mathrm{ml})$ and placed at $4^{\circ} \mathrm{C}$ for $24 \mathrm{~h}$. The mixture was filtered through glass-wool in to 21 ethanol at $-20^{\circ} \mathrm{C}$ with rapid stirring. The resulting chitin suspension was centrifuged at $10000 \mathrm{~g}$ for $20 \mathrm{~min}$; chitin pellets were washed repeatedly with water until the $\mathrm{pH}$ was neutral, and the washed chitin was lyophilized to dryness and stored at $-20^{\circ} \mathrm{C}$. To prepare chitin plate, chitin was resuspended in water $\left(1 \mathrm{mg} \cdot \mathrm{ml}^{-1}\right)$ by passing the suspension over $5 \mathrm{~min}$ through a hand-operated cream homogenizer. The chitin suspension was diluted with an equal volume of $1.6 \%\left(\mathrm{w} \cdot \mathrm{v}^{-1}\right)$ bacto nutrient broth, agar was added to $2 \%\left(\mathrm{w} \cdot \mathrm{v}^{-1}\right)$, the suspension autoclaved, and $10 \mathrm{ml}$ volumes of agar poured into $100 \mathrm{ml}$ Petri plates. After solidification of media a loop full of each strain which was cultured in rich medium (TSB) was placed on the plates (three per plate), and the plates were incubated at $30^{\circ} \mathrm{C}$ for $96 \mathrm{~h}$. Chitin hydrolysis was indicated by zones of clearing around the colonies (Roberts and Cabib, 1982)

\subsection{Production of salicylic acid (SA)}

Strains were grown at $28^{\circ} \mathrm{C}$ for $48 \mathrm{~h}$ on a rotary shaker $(120 \mathrm{rpm})$ in $100 \mathrm{ml}$ flasks containing $50 \mathrm{ml}$ succinate medium (succinic acid, 4.0g; $\mathrm{K}_{2} \mathrm{HPO}_{4}, 6.0 \mathrm{~g} ; \mathrm{KH}_{2} \mathrm{PO}_{4}, 3.0 \mathrm{~g}$; $\left(\mathrm{NH}_{4}\right)_{2} \mathrm{SO}_{4}, 1.0 \mathrm{~g} ; \mathrm{MgSO}_{4} .7 \mathrm{H}_{2} \mathrm{O}, 0.2 \mathrm{~g}$; distilled water, $1000 \mathrm{ml} ; \mathrm{pH} 7.0$ ). Cells were then collected by centrifugation at $6000 \mathrm{~g}$ for $5 \mathrm{~min}$ and $4 \mathrm{ml}$ of cell free culture was acidified with $1 \mathrm{~N} \mathrm{HCl}$ to $\mathrm{pH} 2.0$ and SA was extracted in $\mathrm{CHCl} 3(2 \times 2 \mathrm{ml})$. To the pooled $\mathrm{CHCl}_{3}$ phases, $4 \mathrm{ml}$ of distilled water and 51 of $2 \mathrm{M} \mathrm{FeCl}_{3}$ were added. The absorbance of the purple iron-SA complex, which was developed in the aqueous phase, was read at $527 \mathrm{~nm}$ in a spectrophotometer. A standard curve was prepared with SA dissolved in succinate medium. The quantity of SA in the culture was expressed as $\mathrm{gml}^{-1}$ (Meyer et al., 1992).

\subsection{Dual culture inhibition assays}

Tests were performed in King's medium B agar. Bacterial antagonists were spotted at the sides of the Petri dish ( $10 \mu \mathrm{l}$ of an overnight culture in succinate medium from a single colony) and preincubated at $27^{\circ} \mathrm{C}$ for 2 day. R.solani isolates was then inoculated at center of the bacterial growth in three replicate plates and incubated at $27^{\circ} \mathrm{C}$. Inhibition of fungal growth was assessed 3 day later by measuring the size of the inhibition zone (in $\mathrm{mm}$ ).

\subsection{Data analysis}

Data were analyzed for significance by analysis of variance, followed by Duncan multiple range test $(\alpha=0.01)$, with SAS software (SAS institute, Cary, NC). Normal distribution and homogeneity of variances were checked beforehand. Completely randomized design with four replications was used in all experiments.

\section{Results and Discussion}

In this study 25 isolates of fluorescent pseudomonds (PA1-PA25) were isolated from the wheat rhizosphere collected from different locations of Iran. Production of siderophore, Salicylic acid, chitinase and cyanide hydrogen were evaluated in these isolates and Forty for isolates of Flavobacterium. The results are shown in table $(1,2)$. Many Pseudomonas fluorescens strains are known to secrete fluorescent, yellow-green, water-soluble siderophores under iron-limiting conditions (O, Sullivan and O, Gara, 1992). Belimov et al. (2005) reported that AY197010, AY197006 and AY197009 had the ability to produce siderophores. In this study the results of siderophore production of the fluorescent pseudomonads isolates showed that all of the isolates were able to produce siderophores in form of an orange to dark yellow halo surrounding their colonies in CAS- agar medium. This halo had a clear edge for most of the bacteria. The assay of siderophore production was down by measuring the ratio of halo diameter to colony diameter. Proportion of halo diameter to the colony diameter (the average of three day) of the isolates are between 0.34- 1.21 (table 2). Analysis of variance and means comparison showed that there was a significant difference among the isolates. Production of siderophore in isolate P24 was significantly more than others. Rasouli et al. (2005) reported that 201 indigenous pseudomonas spp. Isolated from Iranian soils were sidrophore producers in CAS-agar medium.

Salicylic acid produced by PGPR in the rhizosphere can play an important role in Induced Systemic Resistance 
(ISR). Salicylic acid production by WCS374, WCS4172 (Leeman et al., 1996), CHA0 Strains of P.fluorescens (Maurhofer et al., 1994) and also 7NSK2 Strain of P.aeruginosa (Demeyer and Hofte, 1997) has been reported. NagaraJkumar et al. (2004) reported that 14 strains of Pseudomonas could produce salicylic acid and its amount varied from $2 \mathrm{mg} \cdot \mathrm{ml}^{-1}$ to $16 \mathrm{mg} \cdot \mathrm{ml}^{-1}$. In our study 11 isolates of studied fluorescent pseudomonads produced different amounts of SA from 0.31 to $10.91 \mathrm{mgml}^{-1}$ in PA23 and PA22 respectively (table 1). Analysis of variance and means comparison showed that there was significant difference among the isolates (table 1). Production of SA by isolate PA22 was significantly more than the others.

A wide range of bacteria have been reported to have chitinase enzyme. The studies done by different researchers showed that $P$. fluorescens could produce this enzyme (Nagarajikuma et al., 2004; Ajit et al., 2006; Saikiar et al., 2005). Lack of this ability has also been reported for some bacteria. O'Brien et al. (1987) reported that the P.putida and P.aerugiuosa in their study did not produce chitinase. In other study Cattelan et al. (1999) showed that GW2103 and LC1118 isolates of Flavobacterium indologenes did not produce chitinase. The results of our study also showed that all of the tested isolates of fluorescent Pseudomonds could not produce chitinase.

Hydrogen cyanide production by some bacteria has been reported (Lork, 1984). Researchers showed that some strains of P.fluorescens, P.aeroginosa and Chromobacterium violaceum can produce hydrogen cyanide (Siddiqui et al., 2003). Anton et al. (1998) introduced some Rhizobial strains as hydrogen cyanide producer. Fluorescent pseudomonads isolates of our study were able to produce of hydrogen cyanide in different ranges. production of hydrogen cyanide by isolates PA25, PA18, PA14, PA11 were at high level(4), by PA2, PA5, PA8, PA19 at relatively high level(3), by PA10, PA20, PA23 at moderate level(2), and other isolates did not produce hydrogen cyanide (1) (Table 1).

Investigation of siderophore, $\mathrm{HCN}$, SA and chitinase production in Flavobacterium isolates exhibited that none of these isolates had ability to produce of these metabolites.

Antifungal activity:

Strains PA24, PA1 and PA18 with 35, 19 and $13 \mathrm{~mm}$ had larger inhibition zone than other strains (table 1). The PA24 and PA1 strains showed significant siderophore production, this may suggest that their antagonistic effects on $R$. solani may be attributed mainly to the production of this metabolite. These results were similar to Ahmad et al. (2007) and Leong-Xian et al. (2005). As it expected none of Flavobacterium isolates exhibit antifungal activity against $R$. solani that it maybe due to inability of this isolates in production antifungal Metabolites.

\section{Acknowledgements}

The authors are grateful to Rouhallah Sharifi, PhD student of plant pathology, department of Bicontrol in Tehran University.

\section{References}

Ahmad F., Ahmad I., Khan M.S. (2006). Screening of free-living rhizospheric bacteria for their multiple plant growth promoting activities. Microbiological Research, 163(2): 173-181. http://dx.doi.org/10.1016/j.micres.2006.04.001

Ajit N.S., Verma R., Shanmugan V. (2006). Extracellular chitinase of fluorescent pseudomonds antifungal to fusarium oxysporum f.sp.dianti causing carnation wilt. Current Microbiology, 52:310-316. http://dx.doi.org/10.1007/s00284-005-4589-3

Alexander D.B., Zuberer D.A. (1991). Use of chrome azurol S reagents to evaluate siderophore production by rhizosphere bacteria. Biology and Fertility of Soils, 12: 39-45. http://dx.doi.org/10.1007/BF00369386

Antoun H., Beauchamp C.J., Goussard N., Chabot R., Lalande R. (1998). Potential of Rhizobium and Bradyrhizobium species as a plant growth promoting rhizobacteria on non legumes. Plant and Soil, 204: 57-67. http://dx.doi.org/10.1023/A:1004326910584

Asghar H.N., Zaeir Z.A., Arshad M. (2004). Screening rhizobacteria for improving the growth ,yield and oil content of canola (Brassica napus L.). Australian Journal of Agricultural Research, 55:187-194. http://dx.doi.org/10.1071/AR03112

Belimov A., Hontzeas A., Safronova N., Demchinskaya V.I., Piluzza S.V., Bulitta G., Glick B.R. (2005). Cadmium-tolerant plant growth-promoting bacteria associated with the roots of Indian mustard (Brassica juncea L. czern.). Soil Biology and Biochemistry, 37: 241-250. http://dx.doi.org/10.1016/j.soilbio.2004.07.033

Bloemberg G.V., Lugtenberg B.J.J. (2001). Molecular basis of plant growth promotion and biocontrol by rhizobacteria. Current Opinion in Plant Biology, 4: 343-350. http://dx.doi.org/10.1016/S1369-5266(00)00183-7 
Cattelan A.J., Hartel P.G., Fuhrmunn J.J. (1999). Screening for plant growth-promoting rhizobacteria to promote early soybean growth. Soil Science Society of America Journal, 63: 1670-1680. http://dx.doi.org/10.2136/sssaj1999.6361670x

De-Meyer G., Hofte M. (1997). Salicylic acid produced by the rhizobacterium Pseudomonas aeruginosa 7NKS2 induces resistance to leaf infection by Botrytis conerea on bean. Phytopathology, 87: 588-593. http://dx.doi.org/10.1094/PHYTO.1997.87.6.588

Donate-Correa J., Leon-Barrios M., Perez-Galdona R. (2004). Screening for plant growth-promoting rhizobacteria in Chamaecytisus proliferus (tagasaste), a forage tree-shrub legume endemic to the Canary Island. Plant and Soil, 266: 261-272. http://dx.doi.org/10.1007/s11104-005-0754-5

Glick B.R. (1995). The enhacement of plant growth by free-living bacteria. Canadian Journal of Microbiology, 41: 109-117. http://dx.doi.org/10.1139/m95-015

Glick B.R., Jacobson C.B., Schwarzek M.M., Pasternak J.J. (1994). 1-aminocyclopropane-1-carboxylix acid deaminase mutants of the plant growth promoting rhizobacterium Pseudomonas putida GR12-2 donot stimulate canola root elongation. Canadian Journal of Microbiology, 40: 911-915. http://dx.doi.org/10.1139/m94-146

Kaaijmakers J.M., Weller D.M. (2001). Exploiting genotypic diversity of 2,4-Diacetylphloroglucinol producing Pseudomonas spp: Characterization of superior root-colonizing P. fluorescens strain Q8r1-96. Applid and Environmental Microbiology, 67:2545-2554. http://dx.doi.org/10.1128/AEM.67.6.2545-2554.2001

King E.O., Ward M.K., Rancey D.E. (1954). Two simple media for the demonstration of pyocanine and fluorescein. Journa of Laboratory and Clinical Medicine, 44:301-307.

Kloepper J.W., Lifshitz R., Zablotwicz R.M. (1989). Free-living bacterial inocula for enhancing crop productivity. Trends in Biotechnology, 7: 39-43. http://dx.doi.org/10.1016/0167-7799(89)90057-7

Krieg N.R., Holt J.G., Williams H.J.H. (1984). Bergeys Manual of Systematic Bacteriology, Vol I, 9th ed.964p.

Leeman M.F., Denouden M., Vanpelt J.A., Dirkx F.P.M, Steijl H., Bakker P.A.H.M., Schippers B. (1996). Iron availibility affects induction of systemic resistance to Fusarium wilt of radish by Pseudomonas fluorescens. Phytopathology, 86: 149-155. http://dx.doi.org/10.1094/Phyto-86-149

Long-Xian R., Miao-Lian X., Bin Z., Bakker P.A.H.M. (2005). Siderophore are main determinant of fluorescent pseudomonads strain in suppressiom of grey mould in eucalyptus urophylla. Acta phytopathologica sinica, 35: $6-12$.

Lork H. (1984). Production of hydrocyanic acid by bacteria. Plant Physiology, 11:142-146.

Maurhofer M., Hase C., Meuwly P., Metraux J.P., Defago G. (1994). Induction of systemic resistance of tobacco to tobacco necrosis virus by the root-colonizeing Pseudomonas fluorescens strain CHAO: influence of the gacA gene and of pyoverdine production. Phytopathology, 88: 139-146. http://dx.doi.org/10.1094/Phyto-84-139

Meyer J.M., Azelvander P., Georges C. (1992). Iron metabolism in Pseudomonas. Salicylic acid, a sidrophore of Pseudomonas fluorescens CHAO. Biofactors, 4: 23-27.

Nagarajkumar M., Bhaskaran R., Velazhahan R. (2004). Involvement of secondary metaboloties and extracellular lytic enzymes produced by Pseudomonas fluorescens in inhibition of Rhizoctonia solani, the rice, sheath blight pathogen. Microbiological Research, 159: 73-81. http://dx.doi.org/10.1016/j.micres.2004.01.005

O'brien M., Colwell R. (1987). A Rapid Test for Chitinase Activity that uses 4-Methylumbelliferyl-N-Acetyl-B-D-Glucosaminide. Applied Environmental Microbialogy, 53(7):1718-1720.

O'sullivan D.J., O'gara F. (1992). Traits of Pseudomonas fluorescens involved in suppression of plant root pathogens. Microbiological. Reviews, 56:662-676.

Raju R.A., Reddy M.N. (1999). Effect of rock phosphate amended with phosphate solubilizing bacteria and farmyard manure in wetland (Oryza sativa). Indian Journal of Agricultural Science, 69: 451-453.

Rassouli M.H., Khavazi K., Rahimian H., Malakouti M.J., Asadi-Rahmani H. (2005). An evaluation of the potential of indigenous Fluorescent Pseudomonds of wheat rhizosphere for producing siderophore. Iran Journal of Soil and Water Science, 20:133-143.

Roberts R.L., Cabib E. (1982). Serratia marcescens chitinase: one-step purification and use for determination of chitin. Annual Biochemistry, 63: 109-120.

Rodriguez H., Fraga R. (1999). Phosphate solubilizing bacteria and their role in plant growth promotion. Biotechnology Advances, 17: 319-339. http://dx.doi.org/10.1016/S0734-9750(99)00014-2 
Saikiar R., Singh B., Kumar R., Arora D. (2005). Detection of pathogenesis-related proteins-chitinase and $\beta$-1,3-glucanse in induced chickpea. Current Science, 89: 659-663.

Siddiqui I.A., Shaukat S.S., Khan G.H., Ali N.I. (2003). Supperssion of Meloidogyne junerica by Pseudomonas aeruginosa IE-6S+ in tomato: the influence of $\mathrm{NaCl}$, oxygen and iron level. Soil Biology and Biochemistry, 35:1625-1634. http://dx.doi.org/10.1016/j.soilbio.2003.08.007

Someya N. (2008). Biological control of fungal plant diseases using antagonistic Bacteria. Journal of General Plant Pathology, 74:459-460. http://dx.doi.org/10.1007/s10327-008-0131-3

Sturz A.V., Nowak J. (2000). Endophytic communities of rhizobacteria and the strategies required to create yield enhancing associations with crops. Applied Soil Ecology, 15: 183-190. http://dx.doi.org/10.1016/S0929-1393(00)00094-9

Vidhyasekaran P., Rabindran R., Muthamilan M., Nayar K., Subramanaian N., Rajappan K., Vasumathi K. (1997). Development of powder formulation of pseudomonas fluorescens for control of rice blast. Plant. Pathology, 46:291-297. http://dx.doi.org/10.1046/j.1365-3059.1997.d01-27.x

Whipps J.M. (2001). Microbiol interactions and biocontrol in the rhizosphere. Journal of Experimental Botany, 52: 487-511.

Table 1. Chitinase, salicylic acid, hydrogen cynanide production and fungal growth inhibition by isolates of fluorescent pseudomonads

\begin{tabular}{|c|c|c|c|c|}
\hline isolates & Hydrogen cyanide & Chitinase enzyme & Salicylic acid & fungal growth inhibition \\
\hline & & & $(\mu \mathrm{g} . \mathrm{mL})$ & $(\mathrm{mm})$ \\
\hline PA1 & 1 & - & $0 \mathrm{~L}$ & $19 \mathrm{~b}$ \\
\hline PA2 & 3 & - & $0 \mathrm{~L}$ & $0 \mathrm{~h}$ \\
\hline PA3 & 1 & - & $3.22 \mathrm{E}$ & $0 \mathrm{~h}$ \\
\hline PA4 & 1 & - & $0 \mathrm{~L}$ & $0 \mathrm{~h}$ \\
\hline PA5 & 3 & - & * & $0 \mathrm{~h}$ \\
\hline PA6 & 1 & - & $1.64 \mathrm{H}$ & $3 g$ \\
\hline PA7 & 1 & - & $1.37 \mathrm{I}$ & $0 \mathrm{~h}$ \\
\hline PA8 & 3 & - & * & $0 \mathrm{~h}$ \\
\hline PA9 & 1 & - & $0 \mathrm{~L}$ & $0 \mathrm{~h}$ \\
\hline PA10 & 2 & - & $0.84 \mathrm{~J}$ & $4 \mathrm{f}$ \\
\hline PA11 & 4 & - & $0 \mathrm{~L}$ & $0 \mathrm{~h}$ \\
\hline PA12 & 1 & - & $0 \mathrm{~L}$ & $3 g$ \\
\hline PA13 & 1 & - & * & $0 \mathrm{~h}$ \\
\hline PA14 & 4 & - & $9.05 \mathrm{~B}$ & $4 \mathrm{f}$ \\
\hline PA15 & 1 & - & $4.02 \mathrm{D}$ & $6 \mathrm{~d}$ \\
\hline PA16 & 1 & - & $\star$ & $0 \mathrm{~h}$ \\
\hline PA17 & 1 & - & $0 \mathrm{~L}$ & $4 \mathrm{f}$ \\
\hline PA18 & 4 & - & $8.52 \mathrm{C}$ & $13 \mathrm{c}$ \\
\hline PA19 & 3 & - & $\star$ & $0 \mathrm{~h}$ \\
\hline PA20 & 2 & - & $2.69 \mathrm{~F}$ & $0 \mathrm{~h}$ \\
\hline PA21 & 1 & - & $2.16 \mathrm{G}$ & $5 e$ \\
\hline PA22 & 1 & - & $10.91 \mathrm{~A}$ & $0 \mathrm{~h}$ \\
\hline PA23 & 2 & - & $0.31 \mathrm{~K}$ & $6 \mathrm{~d}$ \\
\hline PA24 & 1 & - & * & $35 a$ \\
\hline PA25 & 4 & - & $\star$ & $0 \mathrm{~h}$ \\
\hline Range & $1-4$ & - & $0-10.91$ & $0-35$ \\
\hline Average & & - & 2.49 & \\
\hline
\end{tabular}

Values followed by the same letters are not significantly different at $\mathrm{p}=0.01$ Duncan multiple range test $\times$ No growth -No enzyme production
HCN production:
Values followed by the same letters are not significantly different relatively high high HCN scale: Indicator color:

1 yellow

\section{4}

light brown brown 
Table 2. Siderophore production by isolates of fluorescent pseudomonads in CAS agar medium

\begin{tabular}{|c|c|c|c|c|}
\hline & First day & Second day & Third day & Average of three days \\
\hline Isolates & $\begin{array}{c}\text { Ratio of halo } \\
\text { diameter to } \\
\text { colony } \\
\text { diameter }\end{array}$ & $\begin{array}{l}\text { Ratio of halo } \\
\text { diameter to } \\
\text { colony diameter }\end{array}$ & $\begin{array}{l}\text { Ratio of halo } \\
\text { diameter to } \\
\text { colony diameter }\end{array}$ & $\begin{array}{l}\text { Ratio of halo diameter to } \\
\text { colony diameter }\end{array}$ \\
\hline PA1 & $1.05 \mathrm{BCD}$ & $1.00 \mathrm{~B}$ & $0.88 \mathrm{BC}$ & $0.97 \mathrm{BC}$ \\
\hline PA2 & $0.48 \mathrm{HI}$ & $0.53 \mathrm{GH}$ & $0.40 \mathrm{HIJ}$ & $0.47 \mathrm{HIJK}$ \\
\hline PA3 & $1.18 \mathrm{AB}$ & $0.93 \mathrm{BCD}$ & $0.79 \mathrm{BCD}$ & $0.96 \mathrm{BC}$ \\
\hline PA4 & $0.34 \mathrm{I}$ & $0.32 \mathrm{H}$ & $0.36 \mathrm{IJ}$ & $0.34 \mathrm{~K}$ \\
\hline PA5 & $0.88 \mathrm{CDEF}$ & $0.56 \mathrm{GH}$ & $0.48 \mathrm{GHIJ}$ & $0.64 \mathrm{FGHIJ}$ \\
\hline PA6 & $1.31 \mathrm{~A}$ & $0.99 \mathrm{BC}$ & $0.88 \mathrm{BC}$ & $1.06 \mathrm{AB}$ \\
\hline PA7 & $0.68 \mathrm{FGH}$ & $0.50 \mathrm{GH}$ & $0.48 \mathrm{GHIJ}$ & $0.56 \mathrm{GHIJ}$ \\
\hline PA8 & $0.87 \mathrm{CDEF}$ & $0.72 \mathrm{CDEFG}$ & 0.59DEFGH & $0.73 \mathrm{DEFG}$ \\
\hline PA9 & $0.67 \mathrm{FGH}$ & $0.33 \mathrm{H}$ & $0.40 \mathrm{HIJ}$ & $0.46 \mathrm{IJK}$ \\
\hline PA10 & $0.89 \mathrm{CDEF}$ & $0.57 \mathrm{FGH}$ & 0.70BCDEFG & $0.72 \mathrm{DEFG}$ \\
\hline PA11 & $0.78 \mathrm{EF}$ & $0.66 \mathrm{DEFG}$ & $0.59 \mathrm{DEFGH}$ & $0.68 \mathrm{EFG}$ \\
\hline PA12 & $1.10 \mathrm{BC}$ & $0.86 \mathrm{BCDE}$ & 0.71BCDEF & 0.89BCDE \\
\hline PA13 & 0.99BCDE & $0.85 \mathrm{BCDE}$ & $0.83 \mathrm{BC}$ & 0.89BCDE \\
\hline PA14 & $1.14 \mathrm{AB}$ & $0.87 \mathrm{BCDE}$ & $0.75 \mathrm{BCDE}$ & $0.92 \mathrm{BCD}$ \\
\hline PA15 & $0.81 \mathrm{EF}$ & $0.88 \mathrm{BCDE}$ & $0.66 \mathrm{CDEFG}$ & $0.78 \mathrm{CDEF}$ \\
\hline PA16 & $0.82 \mathrm{CEF}$ & $0.57 \mathrm{FGH}$ & 0.61DEFGH & $0.67 \mathrm{FGHI}$ \\
\hline PA17 & $0.55 \mathrm{GHI}$ & $0.51 \mathrm{GH}$ & $0.32 \mathrm{~J}$ & $0.46 \mathrm{JK}$ \\
\hline PA18 & 0.96BCDE & 0.75BCDEFG & $0.55 \mathrm{EFGHI}$ & $0.76 \mathrm{DEFG}$ \\
\hline PA19 & $0.81 \mathrm{EF}$ & $0.71 \mathrm{DEFG}$ & $0.51 \mathrm{FGHIJ}$ & $0.68 \mathrm{FGH}$ \\
\hline PA20 & $0.89 \mathrm{CDEF}$ & $0.64 \mathrm{EFG}$ & $0.61 \mathrm{DEFGH}$ & $0.71 \mathrm{DEFG}$ \\
\hline PA21 & $1.13 \mathrm{AB}$ & $0.85 \mathrm{BCDE}$ & $0.90 \mathrm{~B}$ & $0.96 \mathrm{BC}$ \\
\hline PA22 & $0.86 \mathrm{DEF}$ & $0.65 \mathrm{EFG}$ & $0.56 \mathrm{EFGHI}$ & $0.69 \mathrm{EFG}$ \\
\hline PA23 & $0.52 \mathrm{HI}$ & $0.72 \mathrm{CDEFG}$ & $0.51 \mathrm{FGHIJ}$ & $0.58 \mathrm{FGHIJ}$ \\
\hline PA24 & $1.14 \mathrm{AB}$ & $1.26 \mathrm{~A}$ & $1.23 \mathrm{~A}$ & $1.21 \mathrm{~A}$ \\
\hline PA25 & $0.75 \mathrm{EFG}$ & 0.84BCDEF & $0.55 \mathrm{EFGHI}$ & $0.71 \mathrm{DEFG}$ \\
\hline
\end{tabular}

Values followed by the same letters are not significantly different at $\mathrm{p}=0.01$ Duncan multiple range test 